\title{
Stage IVC Colorectal Cancer AJCC v8
}

National Cancer Institute

\section{Source}

National Cancer Institute. Stage IVC Colorectal Cancer A/CC v8. NCI Thesaurus. Code C134198.

Stage IVC includes: Any T, Any N, M1c. M1c: Metastasis to the peritoneal surface alone or with other site or organ metastases. (AJCC 8th ed.) 